\title{
Commentary: Effectiveness versus efficiency in surgery for DeBakey type I aortic dissection
}

\author{
Ari A. Mennander, MD, PhD
}

\author{
From Tampere University Heart Hospital and Tampere University, Tampere, Finland. \\ Disclosures: Author has nothing to disclose with regard to commercial support. \\ Received for publication Jan 21, 2019; accepted for publication Jan 21, 2019; available ahead of print Feb 21, \\ 2019. \\ Address for reprints: Ari A. Mennander, MD, PhD, Tampere University Heart Hospital, SDSKIR, PL 2000, Tam- \\ pere, Finland (E-mail: ari.mennander@sydansairaala.fi). \\ J Thorac Cardiovasc Surg 2019;158:1296-7 \\ $0022-5223 / \$ 36.00$ \\ Copyright (c) 2019 by The American Association for Thoracic Surgery \\ https://doi.org/10.1016/j.jtcvs.2019.01.077
}

DeBakey type I aortic dissection requires early intervention, often because of its emergency nature, including pericardial tamponade, neurologic deficiency, organ malperfusion, and hemodynamic instability. ${ }^{1}$ Total aortic correction and arch replacement have been a matter of debate because lifesaving surgery is the top priority during emergency; a restricted aortic correction of the ascending aorta such as a hemiarch replacement saves many patients. $^{2,3}$

The current article by Zhang and colleagues ${ }^{4}$ presents a retrospective analysis of patients with DeBakey type I dissection operated by highly experienced surgical teams. Two different contemporaneous surgical techniques, both including an uncompromised aim to perform a 1-step doit-all arch reconstruction ${ }^{5}$ with a distal endograft, are compared. Surgery using a frozen elephant trunk was the method of choice to all patients, especially to those younger than 50 years of age and in whom the true lumen of the aorta required special attention because of compression of the false lumen. The other surgical technique included a hybrid approach to the aortic arch using a retrogradely inserted endograft under moderate hypothermia. The rates of postoperative renal insufficiency, liver insufficiency, and paraplegia were lower after the hybrid operation compared with surgery using frozen elephant trunk under deep hypothermia, but mortality was comparable in both groups. The authors state that the hybrid aortic arch operation is an option for DeBakey type I aortic dissection.

The study did not differentiate aortic dissection as acute, subacute, or chronic, and it was not reported how many patients were lost before reaching surgery. Reasons to perform extended distal surgery were to avoid reoperations and poor false lumen remodeling after surgery. The average age of all patients was remarkably as low as 48.6 years. Yet, the study was underpowered to report on thrombosis of the false lumen during follow-up.

Distal endografting is not routine in young patients with a genetic background. On the other hand, all patients do not develop a distal aortic event and a restricted proximal aortic

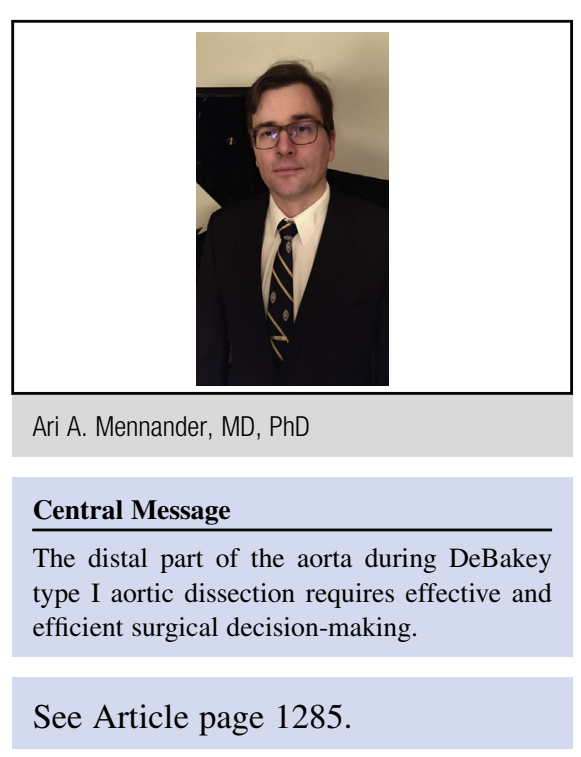

reconstruction suffices for the majority. Even with total reconstruction of the aorta, many if not all patients need lifelong follow-up including imaging control. A 1-stage approach is attractive, but the average surgeon is not convinced, because extended surgery during acute aortic dissection increases risk of complications. ${ }^{6-8}$

Healthcare policy, including reimbursement of costs, availability of cost-effective treatment, and patient followup, is dependent on which part of the world the treatment is offered and affects surgical decision-making. Some patients simply may not have the luxury of being offered a second-stage operation if needed. Nevertheless, surgical principles are acknowledged among all colleagues: First, the patient has to be saved. Second, one tries to minimize immediate risks due to surgery. Only then does long-term prognosis matter for the acute patient.

The exclusion of the dissecting entry tear itself may still be an important technical detail of a successful surgery for aortic dissection. This study demonstrates that the distal part of the aorta may be addressed using at least 2 different surgical strategies.

\section{References}

1. Conzelmann LO, Weigang E, Mehlhorn U, Abugameh A, Hoffmann I, Blettner M, et al. Mortality in patients with acute aortic dissection type A: analysis of pre- and intraoperative risk factors from the German registry for acute aortic dissection type A (GERAADA). Eur J Cardiothorac Surg. 2016;49:e44-52. 
2. Pan E, Gudbjartsson T, Ahlsson A, Fuglsang S, Geirsson A, Hansson EC, et al. Low rate of reoperations after acute type A aortic dissection repair from the Nordic consortium registry. J Thorac Cardiovasc Surg. 2018;156:939-48.

3. Morshuis WJ. Why to be cautious with the use of the frozen elephant trunk in acute type A aortic dissection. J Vis Surg. 2018;4:73.

4. Zhang L, Yu C, Yang X, Sun X, Qiu J, Jiang W, et al. Hybrid aortic repair yields superior outcomes to total arch replacement with frozen elephant trunk in DeBakey type I dissection. J Thorac Cardiovasc Surg. 2019;158:1285-92.

5. Sun L, Qi R, Zhu J, Liu Y, Zheng J. Total arch replacement combined with stented elephant trunk implantation: a new "standard" therapy for type a dissection involving repair of the aortic arch? Circulation. 2011; 123:971-8.

6. Geisbüsch P, Kotelis D, Müller-Eschner M, Hyhlik-Dürr A, Böckler D. Endoleaks in the hybrid procedure? 1. Complications after aortic arch hybrid repair. J Vasc Surg. 2011;53:935-41

7. Di Luozzo G, Griepp RB. Cerebral protection for aortic arch surgery: deep hypothermia. Semin Thorac Cardiovasc Surg. 2012;24:127-30.

8. Cooper WA, Duarte IG, Thourani VH, Nakamura M, Wang NP, Brown WM III, et al. Hypothermic circulatory arrest causes multisystem vascular endothelial dysfunction and apoptosis. Ann Thorac Surg. 2000;69:696-703.

Access to The Journal of Thoracic and Cardiovascular Surgery Online is reserved for print subscribers!

Full-text access to The Journal of Thoracic and Cardiovascular Surgery Online is available for all print subscribers. To activate your individual online subscription, please visit The Journal of Thoracic and Cardiovascular Surgery Online, point your browser to http://www.mosby.com/jtcvs, follow the prompts to activate your online access, and follow the instructions. To activate your account, you will need your subscriber account number, which you can find on your mailing label (note: the number of digits in your subscriber account number varies from 6 to 10 ). See the example below in which the subscriber account number has been circled:

\section{Sample mailing label}

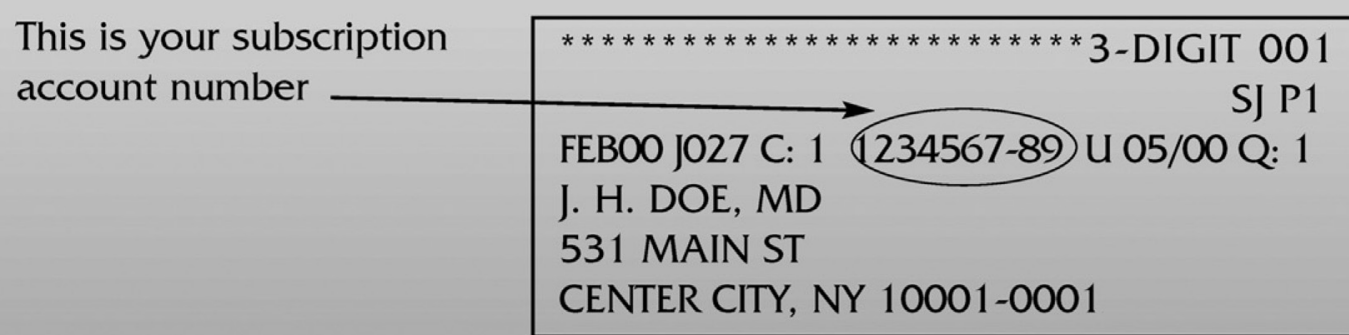

Personal subscriptions to The Journal of Thoracic and Cardiovascular Surgery Online are for individual use only and may not be transferred. Use of The Journal of Thoracic and Cardiovascular Surgery Online is subject to agreement to the terms and conditions as indicated online. 